\title{
Investigation and Risk Assessment of Heavy Metals Contamination around an Abandoned Metal Mine in Korea
}

\author{
Jong-Wha Lee $\cdot$ Soon-Sun Kwak $\cdot$ Sung-Chul Hong $\cdot$ Sang-Il Park $\cdot$ Bong-Ki Jang ${ }^{\dagger}$ \\ Department of Environmental Health Science, Soonchunhyang University, Asan, Korea \\ (Received September 8, 2010/Revised October 20, 2010/Accepted November 29, 2010)
}

\begin{abstract}
Recently, heavy metals contamination of the agricultural soil and crops surrounding mining areas has been identified as one of the most serious environmental problems in South Korea. The Ministry of the Environment in Korea conducted a Preliminary National Environmental Health Survey (PNEHS) in abandoned metal mines in 2007. The priority for a subsequent detailed examination was ranked from the results of PNEHS. The studied mine which was ranked as being of the highest priority is located in the midwestern part of Korea and was operated from 1911 to 1985 . In this study, the contamination levels of the heavy metals in the abandoned metal mine were investigated. From the results, the average daily dose (ADD), target hazard quotient (THQ) and target cancer risk of the heavy metals were evaluated. The concentration of arsenic (As) in all of the tailings from the mine was higher than its countermeasure standard of Korea. In particular, the highest concentration of As, $330 \mathrm{mg} / \mathrm{kg}$, was up to 15 times higher than its countermeasure standard. The average concentration of As in agricultural soils was higher than the warning standard of Korea, and higher than its countermeasure standard at six sites. The average concentrations of the analyzed heavy metals in agricultural soil were below the warning standard, but concentrations of cadmium $(\mathrm{Cd})$ and lead $(\mathrm{Pb})$ at 4 sites were higher than its warning standard. The average concentration of As in surface water exceeded the warning standard of Korea. The value of the THQ of As for the tailings was higher than the health protection standard 1. The value of THQ of As for the farmlands was lower than the standard, while the hazard index (HI) of As was higher than the standard. The value of target cancer risk (TCR) of As, $6.44 \times 10^{-4}$, were higher than the health protection standard of a lifetime risk for TCR at $1 \times 10^{-6}$. This suggests that the residents around the metal mines are exposed to As pollution with a carcinogenic risk.
\end{abstract}

Keywords: abandoned metal mine, heavy metals, risk assessment, hazard index

\section{Introduction}

Soil contamination by metals represents one of the major environmental impacts from Abandoned Mine Sites (AMSs). ${ }^{1)}$ Not only is soil commonly contaminated within the boundaries of AMSs, but also metal compounds may be delivered to soil in the vicinity of an AMS by wind (as dust particles) or by water related pathways (surface runoff, seasonal ground water seepage, shallow ground water table occurrence, or surface water overflow in the flood plains). The characteristics of these

Corresponding author: Department of Environmental Health Science, Soonchunhyang University Tel: 82-41-530-1268, Fax: 82-41-530-1272

E-mail: jangbk@sch.ac.kr pathways are influenced by climatic, hydrologic and hydrogeologic conditions, which determine locations of potentially contaminated areas, where environmental risk of metal contamination in soil is high. Within the conceptual model of the Environmental Pollution Event, soil is considered as a prime recipient of pollution from AMSs, and soil in turn acts as a pathway for metal transformation to vegetation or other elements of the ecosystem.

Coal and metal mining activities were actively developed in South Korea from the early twentieth century, but most of the mines were closed in the 1970s due to economic conditions and the exhaustion of ore reserves. Currently, there are about 1,000 abandoned metal mines in South Korea; most of 
these mines have been left without any management. The tailings from these mines contain several types of toxic contaminants, including heavy metals, and the potential is high for deterioration of the ecosystems around these mines. Recently, heavy metal contamination of agricultural soils and crops surrounding the mining areas has been identified as one of the most serious environmental problems in many countries ${ }^{1-3)}$ including South Korea. ${ }^{4-6)}$

Ministry of environment in Korea conducted 'Preliminary National Environmental Health Survey (PNEHS) in abandoned metal mines' in 2007. For the PNEHS, the health status and heavy metal concentrations in biological samples of the residents around 500 abandoned metal mines in Korea had been examined. The priority for a detailed examination was ranked from the results of PNEHS in 2007. A detailed examination, levels of environmental contamination, health status and heavy metal concentrations of the residents, was performed in 2008 for 10 abandoned metal mines ranked at a group of the highest priority.

The study area, including an abandoned gold/ silver mine, is located in the midwestern part of Korea. During the period of 1999-2003, to tackle potential environmental problems from the mining wastes, the provincial authority undertook remediation strategies including installation of drainage ditches, surface soil cover, and containment/barrier wall and subsequent reclamation mainly focus on the mining dump. However, the mining wastes had been dispersed down slope by surface runoff mainly during heavy rainfall, wind action and draining effluent, which caused contamination of paddy fields, stream sediments and stream waters. The nearest residential area is located within $0.5 \mathrm{~km}$ downstream of the mine portal. The area of flatland within the valley bottom is irrigated from nearby stream waters and/or ground waters. For domestic consumption or commercial sale, the irrigated flatland (paddy fields) is farmed intensively for rice and vegetables.

In this study, contamination levels of heavy metals ( $\mathrm{As}, \mathrm{Cd}, \mathrm{Cu}, \mathrm{Cr}, \mathrm{Hg}, \mathrm{Pb}$ and $\mathrm{Zn}$ ) in the abandoned metal mine were investigated. From the results, average daily dose (ADD), target hazard quotient (THQ) and target cancer risk of heavy metals was evaluated.

\section{Materials and Methods}

\section{Sample collection}

Tailings, agricultural soils, rice grains, sediments, stream and ground water samples were collected from March to June 2008 around the abandoned

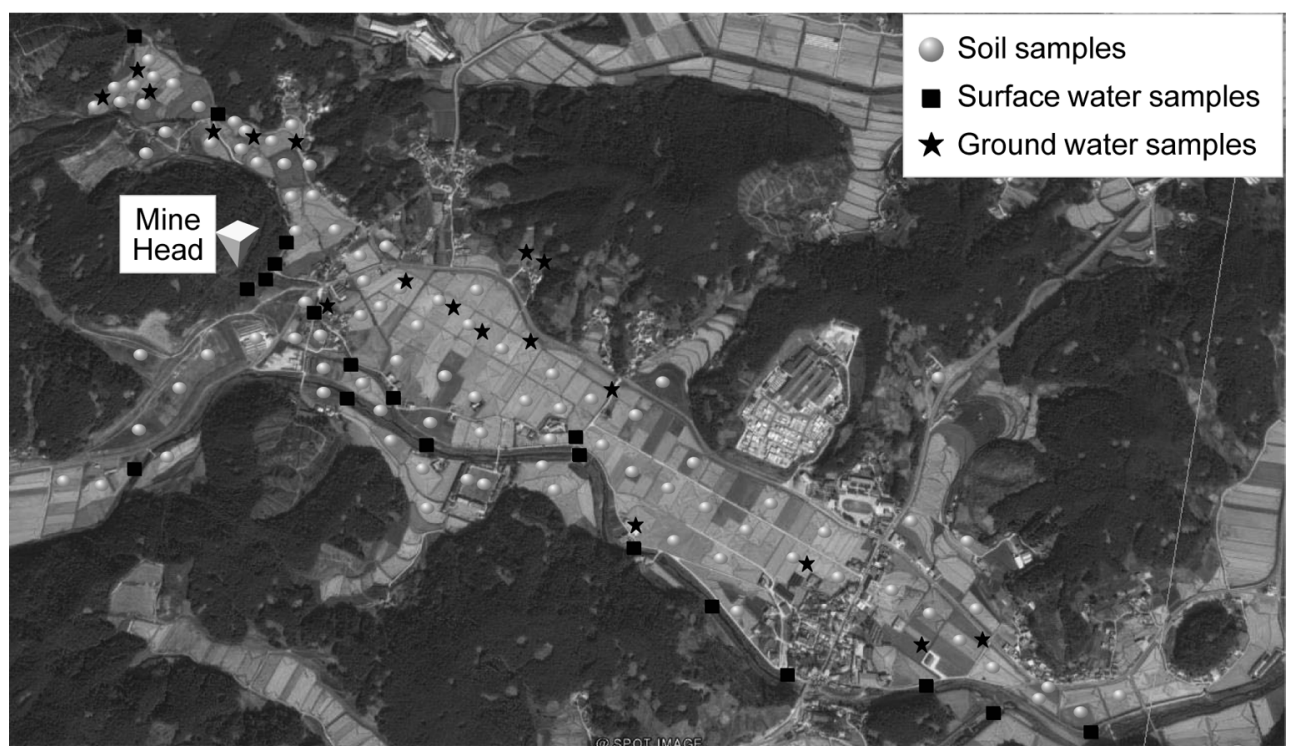

Fig. 1. The sampling sites of soil, surface and ground water. 
metal mine in midwestern part of Korea (Gubong mine, Fig. 1). The mine was operated from 1911 to 1985 . The mineralogy is classified as a $\mathrm{Au} / \mathrm{Ag}$ bearing quartz vein type. Total output of gold and silver was estimated 13.2 and 6.7 tons, respectively. The closure of the mining activity left about 19,000 tons of waste rocks and tailings.

Overall more than 99 soil samples were collected within $2.5 \mathrm{~km}$ from mine. About $3 \mathrm{~kg}$ of one composite tailings sample was composed of 5 subsamples. Agricultural soil samples around the mine area were taken within a depth of $15 \mathrm{~cm}$ from the surface, and each was a composite of 5-7 sub-samples. In order to compare the surface sample with sub-surface sample, six sub-surface soil samples were taken within a depth of $>40 \mathrm{~cm}$ from the surface. All soil samples were collected using a hand auger and then stored in polyethylene bags.

Surface water samples (include 2 leachates) were collected from 21 locations within $2.5 \mathrm{~km}$ downstream areas. Eighteen sediment samples were taken at the same sites. The stream water samples were filtered through a $0.45 \mu \mathrm{m}$ filter, collected in polypropylene bottles and those destined for cation analysis were preserved with ultrapure $\mathrm{HNO}_{3}$ to $\mathrm{pH}<2$. For the ground waters, at least three well volumes of water were purged before sampling, using a low-rate submersible pump attached to a polyethylene (PE) hose. Samples for multi-element analysis were syringefiltered at $0.45 \mu \mathrm{m}$ and preserved using ultra-pure $1 \mathrm{~m} l \mathrm{HNO}_{3}$ in 1,000 $\mathrm{m} l$ HDPE bottles.

\section{Sample pretreatment}

Air dried tailings, agricultural soils and sediments were pretreated according to the Soil Quality Conservation Act of Korea. Samples were disaggregated, sieved on a 10-mesh size $(<2 \mathrm{~mm}$ ) for $\mathrm{As}, \mathrm{Cd}$, total $\mathrm{Cr}, \mathrm{Cu}$ and $\mathrm{Pb}$, and pulverized into a 100 -mesh size $(<150 \mu \mathrm{m})$ for $\mathrm{Hg}$ and $\mathrm{Zn}$. In order to determine the concentrations of $\mathrm{Cd}$, total $\mathrm{Cr}, \mathrm{Cu}$ and $\mathrm{Pb}, 50 \mathrm{ml} 0.1 \mathrm{~N} \mathrm{HCl}$ was added to $10.0 \mathrm{~g}$ of samples. These samples were shaken at $30^{\circ} \mathrm{C}$ for $1 \mathrm{~h}$, and then filtered through filter paper (Whatman 5B). For the analysis of As, $20 \mathrm{~m} l 1 \mathrm{~N} \mathrm{HCl}$ was added to $4.0 \mathrm{~g}$ of samples. These samples were shaken at $30^{\circ} \mathrm{C}$ for $30 \mathrm{~min}$. In order to determine the concentrations of $\mathrm{Hg}$ and $\mathrm{Zn}, 3.3 \mathrm{ml}$ of $\mathrm{HNO}_{3}$ and $10 \mathrm{ml}$ of $\mathrm{HCl}$ (aqua regia) were added to $4.0 \mathrm{~g}$ of the samples. These samples were heated at $70^{\circ} \mathrm{C}$ for $1 \mathrm{~h}$, and then $30 \mathrm{ml}$ of deionized water was added to the solution.

Surface water and groundwater were pre-treated according to the Water Quality Conservation Act of Korea. Briefly, $5 \mathrm{ml} \mathrm{HNO}_{3}$ was added to $500 \mathrm{ml}$ water samples, and then digested on hot plate. Final analytical solutions were made by addition $20 \mathrm{ml}$ of $3 \% \mathrm{HNO}_{3}$, and then filtered through $0.45 \mu \mathrm{m}$ glass filter.

Rice grain samples were taken from the farmlands, and vigorously washed with deionized water to remove soil particles or dust adhered to the crop surface. Samples were then air-dried on covered trays in a filtered-air-drying cabinet at $40^{\circ} \mathrm{C}$ for $48 \mathrm{~h}$. The dry samples were milled, digested with concentrated nitric acid, and added with a diluted acid $\left(5 \% \mathrm{HNO}_{3}\right)$.

\section{Analytical methods}

Soil and water samples were analyzed for $\mathrm{Cd}$, total $\mathrm{Cr}, \mathrm{Cu}, \mathrm{Pb}$ and $\mathrm{Zn}$ concentration by atomic absorption spectrophotometery (AAS 6800, Shimadzu). As was analyzed by hydride generationatomic absorption spectrophotometry (HG-AAS) equipped with hydride vapor generator (HVG-1, Shimadzu, Japan), autosampler (ASC-6100, Shimadzu), atomizer (Atomic muffle furnace, Shimadzu). Hg was assessed by cold vapor AAS (CV-AAS) in which $\mathrm{SnCl}_{2}$ was used as reductant. Rice grain samples were analyzed for $\mathrm{Cd}$ and $\mathrm{Pb}$ by inductively coupled plasma-mass spectrophotometry (ICP-MS). The limits of detection for soil sample were: $4 \mu \mathrm{g} / \mathrm{kg}$ for As, $0.04 \mathrm{mg} / \mathrm{kg}$ for $\mathrm{Cd}, 0.2 \mathrm{mg} / \mathrm{kg}$ for $\mathrm{Cr}, 0.03 \mathrm{mg} / \mathrm{kg}$ for $\mathrm{Cu}, 0.02 \mathrm{mg} /$ $\mathrm{kg}$ for $\mathrm{Hg}, 0.5 \mathrm{mg} / \mathrm{kg}$ for $\mathrm{Pb}$ and $0.1 \mathrm{mg} / \mathrm{kg}$ for $\mathrm{Zn}$. The limits of detection for water sample were: $0.8 \mu \mathrm{g} / l$ for As, $0.9 \mu \mathrm{g} / l$ for $\mathrm{Cd}, 4 \mu \mathrm{g} / l$ for $\mathrm{Cr}$, $0.8 \mu \mathrm{g} / \mathrm{l}$ for $\mathrm{Hg}$ and $10 \mu \mathrm{g} / \mathrm{l}$ for $\mathrm{Pb}$.

\section{Quality control}

Appropriate quality assurance procedures and precautions were carried out to ensure reliability of the results. Double distilled deionized water was used throughout the study. Glassware was properly cleaned, and the reagents were of 
analytical grade. Reagents blank determinations were used to correct the instrument readings. For validation of the analytical procedure, a recovery study was carried out by spiking and homogenizing several already analyzed samples with varied amounts of standard solutions of the metals. The recovery rates for soil and water samples were $100 \pm 5 \%$. Standard reference materials (SRM) obtained from the Korea Analytical Technical Research Institute (Busan, Korea), including soil and water were used for validation of the analytical procedure. The number of sample (40 samples) in one batch, the numbers of point (at least 4 points) and correlation coefficient (more than 0.999) of calibration curve, coefficient of variation $(\mathrm{CV}$, $10 \%)$ of duplicate sample and RSD $(10 \%)$ of the analytical results were included in the internal quality control. Blank and drift standards were run after twenty determinations to maintain instrument calibration. The coefficient of variation of replicate analyses was determined for the measurements to calculate analytical precision.

\section{Risk assessment}

For the risk assessment, evaluation of the average daily dose (ADD), target hazard quotient (THQ) and cancer risk were carried out using Risk Assessment Guidance for Superfund ${ }^{7)}$ and USEPA Region III Risk-Based Concentration Table. ${ }^{8)}$ The exposure parameters were adjusted with physiological and statistical values suitable for Korean people such as mean body weight, life time, and exposure frequencies of various activities. ${ }^{9,10)}$ Three elements, $\mathrm{As}, \mathrm{Cd}$ and $\mathrm{Zn}$ were considered in the assessment based on the database. $\mathrm{Cu} \mathrm{Cr}, \mathrm{Hg}$ and $\mathrm{Pb}$ were excluded in the assessment because of no information of reference dose for chronic oral exposure from the integrated risk information system (IRIS).

Exposure factors used for evaluation of ADDs are listed in Table 1, other factors absent in list are obtained from USEPA. ${ }^{8)}$ For the risk assessment from the mine area, THQ, hazard index (HI) and target cancer risk (TCR) were estimated. THQ was used to indicate the non-carcinogenic risks. TCR was used to indicate carcinogenic risks. The method to estimate THQ and TCR were provided in USEPA Region III Risk-Based Concentration Table. ${ }^{8)}$ Reference doses (RfD) for As, Cd and $\mathrm{Zn}$ were $3 \times 10^{-4}, 5 \times 10^{-4}\left(1 \times 10^{-3}\right.$ for food $)$ and $3 \times 10^{-1}$, respectively. Slope factor (SF) for As was 1.5. The equations for estimating THQ, HI and TCR were as follows: $\mathrm{THQ}=\mathrm{ADD} / \mathrm{RfD}, \mathrm{HI}=$ $\Sigma$ THQs, TCR $=$ ADD $\times$ SF.

\section{Results and Discussion}

\section{Contamination level of heavy metals in the tailings, soils and sediments}

The 0.1-N HCl-extractable concentrations of As $(1-\mathrm{N} \mathrm{HCl}), \mathrm{Cd}, \mathrm{Cr}, \mathrm{Cu}$ and $\mathrm{Pb}$, and total concentrations of $\mathrm{Hg}$ and $\mathrm{Zn}$ in the tailings are listed in Table 2. The $0.1-\mathrm{N} \mathrm{HCl}$ can extract water

Table 1. Using parameters for evaluation of $\mathrm{ADD}$ of $\mathrm{As}, \mathrm{Cd}$ and $\mathrm{Zn}$ with various exposure pathways

\begin{tabular}{lccl}
\hline \hline \multicolumn{1}{c}{ Factors } & Values & Units & \multicolumn{1}{c}{ Comments } \\
\hline Body weight & 57.5 & $\mathrm{~kg}$ & Average BW of residents \\
Skin surface area & 5,700 & $\mathrm{~cm}^{2}$ & US-EPA guidance \\
Exposure duration & 51.2 & years & Duration of residence in the mine area \\
Ingestion rate (soil) & $4.8 \times 10^{-4}$ & $\mathrm{~kg} /$ day & Hawley (1985) $)^{11)}$ Outdoor worker \\
Ingestion rate (water) & 2 & $l /$ day & Ingestion rate of drinking water in Korean adult \\
AF & 0.07 & $\mathrm{mg} / \mathrm{cm}^{2}$ & US-EPA guidance \\
Absorption factor & $\mathrm{CSV}$ & - & Chemical-specific value (CSV) \\
& & As 0.03; Cd 0.001, Cr 0.1; Zn 0.1 \\
GIABS & $\mathrm{CSV}$ & Chemical-specific value (CSV) & As 1; Cd 0.025, Cr 0.013; Zn 1 \\
PC & $1 \times 10^{-3}$ & $\mathrm{~cm} / \mathrm{hr}$ & Default value for untested chemicals \\
Exposure time & 0.5 & hours/day & Average time of shower and swimming of Korean \\
\hline
\end{tabular}

${ }^{a}$ Soil to skin adherence factor, ${ }^{b}$ gastrointestinal absorption factor, ${ }^{c}$ chemical-specific dermal permeability. 
soluble, exchangeable and a part of oxides fractions in the soil. ${ }^{12)}$ Therefore, this method may be related to long-term leacheability of heavy metals. The mine tailings most severely contaminated by As. Concentrations of As in all tailings were higher than its countermeasure standard of Korea. In particular, the highest concentration of As $330 \mathrm{mg} /$ $\mathrm{kg}$, was up to 15 times higher than its countermeasure standard. Average concentrations of the analyzed heavy metals were below its warning standard of Korea, but concentrations of $\mathrm{Cd}$ and $\mathrm{Pb}$ at 3 sites were higher than its warning standard. Although the mine tailings had been cleaned-up and reclaimed for agricultural uses as a remediation strategies at 1999, the contamination levels of the tailings were relatively high. Therefore, the tailings was until undesirable for an agricultural use.

Average concentrations of $\mathrm{As}, \mathrm{Cd}, \mathrm{Hg}, \mathrm{Pb}$ and $\mathrm{Zn}$ in the tailings were significantly higher than those in natural soils, ${ }^{13)}$ and As also higher than the tolerable levels, which are considered as phytotoxically excessive. ${ }^{14)}$ In particular, the average concentration of As was up to 5 times higher than its tolerable level. Because the concentrations of $\mathrm{As}, \mathrm{Cd}, \mathrm{Cr}, \mathrm{Cu}$ and $\mathrm{Pb}$ except $\mathrm{Hg}$ and $\mathrm{Zn}$ are $0.1-\mathrm{N}$ $\mathrm{HCl}-\mathrm{extractable}$ concentrations (1-N for As), total concentrations of $\mathrm{As}, \mathrm{Cd}, \mathrm{Cr}, \mathrm{Cu}$ and $\mathrm{Pb}$ may be higher than those in Table 2.

The 0.1-N HCl-extractable concentrations of As (1-N $\mathrm{HCl}), \mathrm{Cd}, \mathrm{Cr}, \mathrm{Cu}$ and $\mathrm{Pb}$, and total concentrations of $\mathrm{Hg}$ and $\mathrm{Zn}$ in agricultural soils are also listed in Table 2. Average concentrations of As in agricultural soils were higher than its warning standard of Korea, and were higher than its countermeasure standard at six sites. Average concentrations of the analyzed heavy metals in agricultural soils were below its warning standard of Korea, but concentrations of $\mathrm{Cd}$ and $\mathrm{Pb}$ at 4 sites were higher than its warning standard. Concentrations of heavy metals in this study were lower than those of previous researches for several AMSs left without any management. ${ }^{6,16}$ Average concentrations of $\mathrm{As}$ and $\mathrm{Zn}$ were higher than those in natural soils. Average concentrations of all analyzed elements were lower than its tolerable levels, but a paddy field soil which is adjacent to the tailing piles presented the highest values of As $98.0 \mathrm{mg} / \mathrm{kg}$ (data were not shown).

Table 2 also shows the levels of heavy metals in stream sediment. Stream sediment was severely contaminated by As and $\mathrm{Cd}$. Average concentrations of As and Cd were higher than its countermeasure

Table 2. Average and entire range (in parenthesis) of heavy metal concentrations in tailings and agricultural soils

\begin{tabular}{|c|c|c|c|c|c|c|c|c|c|}
\hline & Sample & $\mathrm{N}$ & $\begin{array}{c}\text { As } \\
(\mathrm{mg} / \mathrm{kg})\end{array}$ & $\begin{array}{c}\mathrm{Cd} \\
(\mathrm{mg} / \mathrm{kg})\end{array}$ & $\begin{array}{c}\mathrm{Cr} \\
(\mathrm{mg} / \mathrm{kg})\end{array}$ & $\begin{array}{c}\mathrm{Cu} \\
(\mathrm{mg} / \mathrm{kg})\end{array}$ & $\begin{array}{c}\mathrm{Hg} \\
(\mathrm{mg} / \mathrm{kg})\end{array}$ & $\begin{array}{c}\mathrm{Pb} \\
(\mathrm{mg} / \mathrm{kg})\end{array}$ & $\begin{array}{c}\mathrm{Zn} \\
(\mathrm{mg} / \mathrm{kg}) \\
\end{array}$ \\
\hline \multicolumn{2}{|l|}{ Tailings } & 7 & $\begin{array}{c}99.0 \\
(7.6-330.7)\end{array}$ & $\begin{array}{c}1.1 \\
(\mathrm{ND}-2.8)\end{array}$ & $\begin{array}{c}1.0 \\
\text { (ND-2.7) }\end{array}$ & $\begin{array}{c}5.9 \\
(0.8-12.6)\end{array}$ & $\begin{array}{c}1.7 \\
(0.2-4.6)\end{array}$ & $\begin{array}{c}60.7 \\
(7.4-129.8)\end{array}$ & $\begin{array}{c}148.8 \\
(72.1-201.1)\end{array}$ \\
\hline \multicolumn{2}{|l|}{ Garden } & 18 & $\begin{array}{c}15.6 \\
(\mathrm{ND}-179.0)\end{array}$ & $\begin{array}{c}0.2 \\
\text { (ND-0.8) }\end{array}$ & $\begin{array}{c}0.8 \\
\text { (ND-2.6) }\end{array}$ & $\begin{array}{c}4.8 \\
(0.9-11.8)\end{array}$ & $\begin{array}{c}0.6 \\
(0.1-2.4)\end{array}$ & $\begin{array}{c}8.6 \\
(0.9-16.2)\end{array}$ & $\begin{array}{c}121.4 \\
(84.4-181.5)\end{array}$ \\
\hline \multicolumn{2}{|l|}{ Paddy } & 84 & $\begin{array}{c}7.2 \\
(0.2-213.4)\end{array}$ & $\begin{array}{c}0.2 \\
(\mathrm{ND}-2.1)\end{array}$ & $\begin{array}{c}0.4 \\
(\mathrm{ND}-3.3)\end{array}$ & $\begin{array}{c}5.2 \\
(2.0-13.4)\end{array}$ & $\begin{array}{c}0.3 \\
\text { (ND-3.3) }\end{array}$ & $\begin{array}{c}11.9 \\
(3.3-45.7)\end{array}$ & $\begin{array}{c}93.9 \\
(54.3-173.0)\end{array}$ \\
\hline \multirow[t]{2}{*}{ Paddy } & - surface & 6 & $\begin{array}{c}3.3 \\
(0.3-14.9)\end{array}$ & $\begin{array}{c}0.6 \\
(0.1-2.1)\end{array}$ & $\begin{array}{c}0.4 \\
\text { (ND-1.3) }\end{array}$ & $\begin{array}{c}5.8 \\
(4.0-10.1)\end{array}$ & $\begin{array}{c}0.2 \\
\text { (ND-0.6) }\end{array}$ & $\begin{array}{c}14.6 \\
(10.7-20.2)\end{array}$ & $\begin{array}{c}92.4 \\
(88.5-112.5)\end{array}$ \\
\hline & - subsurface & 6 & $\begin{array}{c}5.5 \\
(0.3-9.5)\end{array}$ & $\begin{array}{c}0.4 \\
(\mathrm{ND}-0.9)\end{array}$ & $\begin{array}{c}0.7 \\
\text { (ND-1.5) }\end{array}$ & $\begin{array}{c}7.4 \\
(2.5-10.9)\end{array}$ & $\begin{array}{c}0.5 \\
(0.2-0.8)\end{array}$ & $\begin{array}{c}26.0 \\
(11.1-45.7)\end{array}$ & $\begin{array}{c}98.5 \\
(77.6-121.1)\end{array}$ \\
\hline \multicolumn{2}{|c|}{ Stream sediment } & 16 & $\begin{array}{c}114.5 \\
(2.5-396.5)\end{array}$ & $\begin{array}{c}3.5 \\
(0.1-11.2)\end{array}$ & ND & - & $\begin{array}{c}0.4 \\
(0.2-1.0)\end{array}$ & $\begin{array}{c}55.9 \\
(2.2-163.0)\end{array}$ & - \\
\hline \multicolumn{2}{|c|}{ World average in soil ${ }^{\mathrm{a}}$} & & 6.0 & 0.35 & $20-200^{c}$ & 30 & $0.03^{\mathrm{c}}$ & 35 & 90 \\
\hline \multicolumn{2}{|c|}{ Tolerable level $^{\mathrm{b}}$} & & 20 & 3.0 & - & 100 & - & 100 & 300 \\
\hline \multirow{2}{*}{$\begin{array}{l}\text { Korean } \\
\text { Standard }\end{array}$} & Warning & & 6 & 1.5 & - & 50 & 4 & 100 & 300 \\
\hline & Countermeasure & & 15 & 4 & - & 125 & 10 & 300 & 700 \\
\hline
\end{tabular}

${ }^{a}$ Bowen $(1979)^{13)}$, 'Kabata-Pendias and Pendias $(1984)^{14)}$, ${ }^{c} \mathrm{Xie}$ and $\mathrm{Lu}(2000)^{15)}$. 
and warning standard of Korea, respectively. Heavy metal contamination of sediments can critically degrade aquatic systems. ${ }^{17,18)}$ Their release from the sediment can make them enter the aquatic ecosystems and bring about severe problems. ${ }^{19)}$ Although the mine had been closed 24 years ago, stream sediments were until severely contaminated with As and $\mathrm{Cd}$. Therefore, further research on the contamination sources and ecological risk of heavy metals in sediments should be performed.

\section{Contamination level of heavy metals in agri-} cultural soils as influenced by uses, depth and distance

The average concentrations of $\mathrm{As}$ and $\mathrm{Zn}$ in gardens were significantly higher than those in paddy. Because paddy fields are irrigated every year in Korea, metals in paddy might have opportunities for extraction into the irrigated water. Average concentrations of $\mathrm{As}, \mathrm{Cr}, \mathrm{Cu} \mathrm{Hg}$, $\mathrm{Pb}$ and $\mathrm{Zn}$ except $\mathrm{Cd}$ in subsurface soils of paddy were higher than those in surface soils (Table 2).

The levels of metals in agricultural soils according to distance from the minehead are shown in Table 3. The levels of heavy metals were inversely proportional to the distance from the center of the mine.

\section{Contamination level of heavy metals in surface water, ground water and vegetables}

Table 4 shows the levels of metals in stream waters, ground water and vegetables nearby the metal mine. Average concentration of As exceeded the surface water standard of Korea. Concentrations of $\mathrm{Cr}, \mathrm{Hg}$ and $\mathrm{Pb}$ were below detection limits throughout the monitoring period. The levels of analyzed elements in ground water at all sites were below the ground water standard of Korea. Average concentrations of $\mathrm{Cd}$ and $\mathrm{Pb}$ in vegetables were 0.025 (ND-0.450) and 0.037 (ND-0.162) $\mathrm{mg} / \mathrm{kg}$, respectively. There was not a positive correlation between the levels of $\mathrm{Cd}$ and

Table 3. Average and SD of heavy metal concentrations in agricultural soils by distance from the minehead

\begin{tabular}{ccccccccc}
\hline \hline $\begin{array}{c}\text { Distance from } \\
\text { mine head }\end{array}$ & No. & As & $\mathrm{Cd}$ & $\mathrm{Cr}$ & $\mathrm{Cu}$ & $\mathrm{Hg}$ & $\mathrm{Pb}$ & $\mathrm{Zn}$ \\
\hline $\begin{array}{c}<0.5 \mathrm{~km} \\
0.5\end{array}$ & $24.3 \pm 62.3$ & $0.41 \pm 0.61$ & $0.80 \pm 0.75$ & $5.6 \pm 2.7$ & $0.59 \pm 0.90$ & $21.7 \pm 28.2$ & $108.6 \pm 34.9$ \\
$0.1 \mathrm{~km}$ & 22 & $1.6 \pm 1.7$ & $0.21 \pm 0.12$ & $0.22 \pm 0.35$ & $4.2 \pm 2.2$ & $0.21 \pm 0.25$ & $10.1 \pm 4.2$ & $91.0 \pm 12.5$ \\
$1-2.5 \mathrm{~km}$ & 32 & $1.1 \pm 0.7$ & $0.15 \pm 0.08$ & $0.10 \pm 0.20$ & $4.3 \pm 2.3$ & $0.16 \pm 0.19$ & $6.9 \pm 3.0$ & $93.7 \pm 18.9$ \\
\hline $\begin{array}{c}\text { p-value } \\
\text { (ANOVA) }\end{array}$ & 0.03 & 0.02 & $<0.01$ & 0.02 & $<0.01$ & $<0.01$ & 0.01 \\
\hline
\end{tabular}

Table 4. Average and entire range (in parenthesis) of heavy metal concentrations in surfacewater, groundwater and rice grain

\begin{tabular}{|c|c|c|c|c|c|c|}
\hline Sample & No. & As $(\mu \mathrm{g} / l)$ & $\mathrm{Cd}(\mu \mathrm{g} / l)$ & $\mathrm{Cr}(\mu \mathrm{g} / l)$ & $\overline{\mathrm{Hg}(\mu \mathrm{g} / l)}$ & $\mathrm{Pb}(\mu \mathrm{g} / l)$ \\
\hline Surfacewater & 21 & $\begin{array}{c}0.06 \\
(0.003-0.27)\end{array}$ & $\begin{array}{c}0.004 \\
(0.003-0.01)\end{array}$ & ND & ND & ND \\
\hline Groundwater & 19 & $\begin{array}{c}0.009 \\
(0.001-0.04)\end{array}$ & $\begin{array}{c}0.004 \\
(0.003-0.01)\end{array}$ & ND & ND & ND \\
\hline $\begin{array}{l}\text { Korea drinking } \\
\text { water standard }\end{array}$ & & 0.05 & 0.005 & 0.05 & 0.001 & 0.05 \\
\hline $\begin{array}{l}\text { Korea surface } \\
\text { water standard }\end{array}$ & & 0.05 & 0.01 & 0.05 & ND & 0.1 \\
\hline Rice grain & 43 & - & $\begin{array}{c}0.025 \mathrm{mg} / \mathrm{kg} \\
(\mathrm{ND}-0.450)\end{array}$ & - & - & $\begin{array}{c}0.037 \mathrm{mg} / \mathrm{kg} \\
(\mathrm{ND}-0.162)\end{array}$ \\
\hline Normal value ${ }^{a}$ & & & 0.06 & & & 0.44 \\
\hline
\end{tabular}


$\mathrm{Pb}$ in vegetables and those in agricultural soils (data were not shown).

\section{Risk assessment from the mine area}

An exposure assessment is the qualitative or quantitative estimation of the magnitude, frequency, duration and route of exposure for each potential and actual receptor population in the risk assessment. The source media, transport mechanism, exposure media and receptors were chosen to describe the specific environmental conditions of the mine areas. $^{20)}$ Present use of the study sites is agricultural activity and residential without mining activity, and future use is expected to remain as the same activity. The area surrounding the mine sites commonly consists of residential housing with various distances from each mine site and paddy or farmland uses. Agricultural areas are distributed in the down-gradient directly or indirectly from the mine area, and farmers can be exposed to the contaminants through the ingestion and dermal contact of soils, the crops and waters.

Average daily doses (ADD) of As, $\mathrm{Cd}$ and $\mathrm{Zn}$ with various exposure pathways are shown in Table 5. As is a carcinogenic toxic chemical and
$\mathrm{Cd}$ and $\mathrm{Zn}$ are considered as non-carcinogenic toxic chemicals. ${ }^{9)} \mathrm{Cu} \mathrm{Cr}, \mathrm{Hg}$ and $\mathrm{Pb}$ were excluded in the assessment because of no information of reference dose for chronic oral exposure from the integrated risk information system (IRIS). Because the tailing had been cleaned-up and reclaimed for future agricultural uses, ADD through the tailing was included in the list. The order of ADD for As through various exposure pathways was tailing $>$ groundwater $>$ farmland. The order of ADD for $\mathrm{Cd}$ through various exposure pathways was groundwater $>$ rice grain $>$ farmland.

Table 6 shows THQ, hazard index (HI) and target cancer risk (TCR) of $\mathrm{As}, \mathrm{Cd}$ and $\mathrm{Zn}$. The value of THQ of As for intake through the tailing was higher than the health protection standard 1. ${ }^{9,21)}$ The value of THQ of As for intake through the farmland was lower than the standard, while the hazard index (HI) of As was higher than the standard. The risk was mainly contributed by As $(\mathrm{HI}=1.07)$, which may cause chronic noncarcinogenic effects, such as jaundice, cirrhosis, blueness of the extremities, Raynaud's syndrome, blackfoot disease (a type of gangrene), anemia, and hyperkeratosis of the skin. ${ }^{22)}$ The HI value of

Table 5. Results of ADDs for As, Cd and $\mathrm{Zn}$ with various exposure pathways

\begin{tabular}{|c|c|c|c|c|}
\hline \multirow{2}{*}{\multicolumn{2}{|c|}{ Exposure pathway }} & \multicolumn{3}{|c|}{ Average daily dose ${ }^{\dagger}$ (mg/kg-day) } \\
\hline & & As & $\mathrm{Cd}$ & $\mathrm{Zn}$ \\
\hline \multirow{3}{*}{ Soil } & Tailing & $8.12 \times 10^{-4}$ & $8.81 \times 10^{-6}$ & $1.29 \times 10^{-3}$ \\
\hline & Garden & $1.28 \times 10^{-4}$ & $1.76 \times 10^{-6}$ & $1.05 \times 10^{-3}$ \\
\hline & Paddy & $0.59 \times 10^{-4}$ & $1.84 \times 10^{-6}$ & $0.85 \times 10^{-3}$ \\
\hline \multicolumn{2}{|c|}{ Groundwater } & $3.01 \times 10^{-4}$ & $1.34 \times 10^{-4}$ & - \\
\hline \multicolumn{2}{|c|}{ Rice grain } & - & $6.64 \times 10^{-6}$ & - \\
\hline
\end{tabular}

${ }^{\mathrm{ADD}}$ in soil and groundwater is sum of the ingestion and dermal pathways.

Table 6. Results of THQ and carcinogenic risk assessment of $\mathrm{As}, \mathrm{Cd}$ and $\mathrm{Zn}$ for contaminated soil and groundwater

\begin{tabular}{cccccc}
\hline \hline \multirow{2}{*}{ Exposure pathways } & \multicolumn{3}{c}{ THQ } & \multirow{2}{*}{ TCR for As } \\
\cline { 3 - 5 } & Tailing & As & Cd & Zn & \\
\hline \multirow{3}{*}{ Soil } & 2.03 & 0.02 & $<0.01$ & $1.22 \times 10^{-3}$ \\
& Garden & 0.32 & $<0.01$ & $<0.01$ & $1.92 \times 10^{-4}$ \\
& Paddy & 0.15 & $<0.01$ & $<0.01$ & $0.89 \times 10^{-4}$ \\
\hline \multicolumn{2}{c}{ Groundwater } & 0.75 & 0.27 & - & $4.52 \times 10^{-4}$ \\
\hline \multicolumn{2}{c}{ Sum of THQ and TCR $^{\dagger}$} & - & $<0.01$ & - & - \\
\hline
\end{tabular}

The values are sum of garden soil and other pathway. 
$\mathrm{Zn}$ and $\mathrm{Cd}$ mixture 0.29 , lower than the standard 1 , demonstrated that intake of soil, water and rice does not result in overexposure of these two chemicals.

Since $\mathrm{Zn}$ and $\mathrm{Cd}$ do not cause any carcinogenic effects, only the TCR value for intake of As was calculated to indicate the carcinogenic risk. The values of TCR of As $6.44 \times 10^{-4}$ for intake through all exposure pathways were higher than the health protection standard of lifetime risk for TCR $1 \times 10^{-6}$. $^{8)}$ It shows that the residents of the mine could be exposed to As pollution with a carcinogenic risk. There are about 1,000 abandoned metal mines in South Korea; most of these mines have been left without any management. Most agricultural soils of abandoned metal mines were severely contaminated by heavy metals. Recently, the concentrations of urinary arsenic of Korean general population was reported to be approximately $50 \mu \mathrm{g} / l$ (in press). Although seafoods are considered as the main contamination sources, the contribution of As contaminated soil, ground water or/and crops to the body burden of arsenic should be examined.

Soil and crops contamination by metals has represented one of the major environmental impacts from mine. Excessive accumulation of heavy metals in agricultural soils around mining areas, resulting in elevated heavy metal uptake by food crops, is of great concern because of potential health risk to the local inhabitants. ${ }^{23-25}$ ) The target hazard quotient (THQ) of rice grown in the vicinity of a mine varied from 0.66.0.89 for $\mathrm{Cu}$, 0.48.0.60 for $\mathrm{Zn}, 1.43 .1 .99$ for $\mathrm{Pb}$, and 2.61.6.25 for Cd. Estimated daily intake (EDI) and THQs for $\mathrm{Cd}$ and $\mathrm{Pb}$ of rice and vegetables exceeded the FAO/WHO permissible limit. Heavy metal contamination of food crops grown around the mine posed a great health risk to the local population through consumption of rice and vegetables. $^{26}$ Li et al. $(2006)^{27)}$ calculated an environmental quality index $(\mathrm{Pi})$ values for heavy metals in soils around a mine. $\mathrm{Pi}$ values for $\mathrm{Pb}$, $\mathrm{Zn}, \mathrm{Cd}$ exceeded 1, confirming that the soils were highly polluted. It is therefore recommended that farmers should not grow agricultural foods such as edible vegetables in this area unless the soil is remediated. Hongyu Liu et al. $(2005)^{28)}$ reported that the daily intake amounts of $\mathrm{Cu}, \mathrm{Zn}, \mathrm{Cd}$ and $\mathrm{Pb}$ from the cereal and vegetables grown around a lead/zinc mine are much higher than the recommended level. Tükdogan et al. (2002) ${ }^{29)}$ suggested that the high prevalence of upper gastrointestinal cancer rates in the Van region of Turkey was related to the high concentration of heavy metals in the soil, fruit and vegetables.

\section{Conclusions}

During the period of 1999-2003, to tackle potential environmental problems from the mining wastes, the provincial authority undertook remediation strategies. Nevertheless, the levels of heavy metals in biological samples of residents in this study area had been relatively high. Average concentrations of As in agricultural soils were higher than its warning standard of Korea, and were higher than its countermeasure standard at six sites. Average concentrations of the analyzed heavy metals in agricultural soils were below its warning standard of Korea, but concentrations of $\mathrm{Cd}$ and $\mathrm{Pb}$ at 4 sites were higher than its warning standard. Average concentration of As in surface water exceeded the standard of Korea.

The value of THQ of As for intake through the tailing was higher than the health protection standard 1. The value of THQ of As for intake through the farmland was lower than the standard, while the hazard index (HI) of As was higher than the standard. The values of target cancer risk (TCR) of As $6.44 \times 10^{-4}$ for intake through all exposure pathways were higher than the health protection standard of lifetime risk for TCR $1 \times 10^{-6}$. It means that the residents around the mine could be exposed to As pollution with a carcinogenic risk. Therefore the contribution of As contaminated soil, ground water or/and crops to the body burden of arsenic should be examined.

\section{References}

1. Thornton, I. : Sources and pathways of arsenic in south-west England. University of Missouri, 93103, 1995.

2. Aslibekian, O. and Moles, R. : Environmental risk assessment of metals contaminated soils at silvermines abandoned mine site, Co Tipperary, 
Ireland. Environmental Geochemistry and Health, 25, 247-266, 2003.

3. Liu, H., Probst, A. and Liao, B. : Metal contamination of soils and crops affected by the Chenzhou lead/ zinc mine spill (Hunan, China). Science of the Total Environment, 339, 153-166, 2005.

4. Jung, M. C. and Thornton, I. : Heavy metal contamination of soils and plants in the vicinity of a lead-zinc mine, Korea. Applied Geochemistry, 11, 53-59, 1996.

5. Min, J. S., Cheong, Y. W., Lee, H. J. and Lee, D. N. : A study on the environmental \& safety problems and their remediation around mining areas. Kungmoonsa, Taejun, Korea, 1997.

6. Kim, J. Y., Kim, K. W., Ahn, J. S., Ko, I. W. and Lee, C. H. : Investigation and risk assessment modeling of As and other heavy metals contamination around five abandoned metal mines in Korea. Environmental Geochemistry and Health, 27, 193203, 2005.

7. USEPA (Environmental Protection Agency) : Risk assessment guidance for Superfund. EPA/540/R-92/ 003, Washington, DC, USEPA, 1991.

8. USEPA : Integrated risk information systemdatabase. Philadelphia PA, Washington, DC, 2007.

9. USEPA : Test methods for evaluating solid wastes, Physical/Chemical Methods (SW846). Washington, DC, US Government Printing Office, 1997.

10. Lee, J. S., Klinck, B. and Moore, Y. : Dispersal risk assessment modelling and bioavailability of arsenic and other toxic heavy metals in the vicinity of two abandoned mine sites in Korea. British Geological Technical Report, 2000.

11. Hawley, J. K. : Assessment of health risk from exposure to contaminated soil. Risk Analysis, 5, 289-302, 1985.

12. Adriano, D. C. : Trace elements in the terrestrial environment. New York Inc., Springer-Verlag, 1986.

13. Bowen, H. J. M. : Environmental chemistry of elements. Academic Press, London, 1979.

14. Kabata-Pendias, A. and Pendias, H. : Trace elements in soils and plants. Boca Raton, CRC Press, 1984.

15. Xie, Z. M. and Lu, S. G. : Trace elements and environmental quality. China: Guizhou Science Technology Press, 208-216, 2000.

16. Lee, J. S., Klinck, B. and Chon, H. T. : Human risk assessment modeling of arsenic and toxic heavy metals. The Korean Society for Geosystem Engineering, 38, 136-145, 2001.

17. Charkhabi, A. H., Sakizadeh, M. and Rafiee, G. : Seasonal fluctuation in heavy metal pollution in Iran's Siahroud River. Environmental Science and Pollution Research International, 12, 264-270, 2005.

18. Zhenli, L. H., Xiaoe, E. Y. and Stoffella, P. J. :
Trace elements in agroecosystems and impacts on the environment. Journal of Trace Elements in Medicine and Biology, 19, 125-140, 2005.

19. Mohammed, M. H. and Markert, B. : Toxicity of heavy metals on Scenedesmus quadricauda (Turp.) de Brebisson in batch cultures. Environmental Science and Pollution Research International, 13, 98-104, 2006.

20. ASTM (American Society for Testing and Materials) : Standard guide for risk-based corrective action applied at petroleum release sites. E1739-95, Philadelphia, PA: Annual book of ASTM standards, 1995.

21. Lin, M. C. : Risk assessment on mixture toxicity of arsenic, zinc and copper intake from consumption of milkfish, Chanos chanos (Forsskål), cultured using contaminated groundwater in Southwest Taiwan. Bulletin of Environmental Contamination and Toxicology, 83(1), 125-129, 2009.

22. Tseng, C. H., Huang, Y. K., Huang, Y. L., Chung, C. J., Yang, M. H., Chen, C. J. and Hsueh, Y. M. : Arsenic exposure, urinary arsenic speciation, and peripheral vascular disease in blackfoot diseasehyperendemic villages in Taiwan. Toxicology and Applied Pharmacology, 206, 299-308, 2005.

23. Adriano, D. C. : Trace elements in terrestrial environments: biogeochemistry, bioavailability and risks of metals. 2nd edition. Springer-Verlag, 2001.

24. Muchuweti, M., Birkett, J. W., Chinyanga, E., Zvauya, R., Scrimshaw, M. D. and Lester, J. N. : Heavy metal content of vegetables irrigated with mixtures of wastewater and sewage sludge in Zimbabwe: implications for human health. Agriculture Ecosystems and Environment, 112, 41-48, 2006.

25. Pruvot, C., Douay, F., Herve, F. and Waterlot, C. : Heavy metals in soil, crops and grass as a source of human exposure in the former mining areas. Journal of Soils Sediments, 6, 215-220, 2006.

26. Zhuang, P., McBride, M. B., Xia, H., Li, N. and Li, Z. : Health risk from heavy metals via consumption of food crops in the vicinity of Dabaoshan mine, South China. Science of the Total Environment, 407, 1551-1561, 2009.

27. Li, J., Xie, Z. M., Xu, J. M. and Sun, Y. F. : Risk assessment for safety of soils and vegetables around a lead/zinc mine. Environmental Geochemistry and Health, 28, 37-44, 2006.

28. Liu, H., Probst, A. and Liao, B. : Metal contamination of soils and crops affected by the Chenzhou lead/ zinc mine spill (Hunan, China). Science of the Total Environment, 339, 153-166, 2005.

29. Tükdogan, M. K., Kilicel, F., Kara, K., Tuncer, I., and Uygan, I. : Heavy metals in soil, vegetables and fruits in the endemic upper gastrointestinal cancer region of Turkey. Environmental Toxicology and Pharmacology, 13, 175-179, 2002. 